\title{
A study on Apple ber to identify the suitability of new product development
}

\author{
Mathangi S \& Prakash Maran J \\ Department of Food Science and Nutrition, Periyar University, Salem, Tamil Nadu, India
}

\section{Article history}

Received: 21 October 2019

Accepted: 06 December 2019

Published: 01 January 2020

\section{Publisher}

Horizon e-Publishing Group

\author{
*Correspondence \\ S.Mathangi \\ 凶talk2mathangi@gmail.com
}

\begin{abstract}
This study emphasis on the physico-chemical properties of a new ber variety (Apple ber) originated in Thailand and slowly emerging in many parts of the world. The analysis is done under two different conditions the one being controlled and second one is blanched. The analysis revealed that the controlled condition is superior in physico-chemical properties than the blanched one. Also, proximate analysis was carried out on the fruit and its powdered form. In this analysis also controlled condition parameters were ahead of blanched. New products were developed with the Apple ber powder.
\end{abstract}

Keywords: Apple ber; Physico-chemical properties; Proximate Analysis

Citation: Mathangi S, Maran J P. A study on Apple ber to identify the suitability of new product development. Plant Science Today 2020;7(1):61-69. https://doi.org/10.14719/pst.2020.7.1.640

Copyright: (C) Mathangi \& Maran (2020). This is an open-access article distributed under the terms of the Creative Commons Attribution License, which permits unrestricted use, distribution, and reproduction in any medium, provided the original author and source are credited (https://creativecommons.org/licenses/by/4.0/).

Indexing: Plant Science Today is covered by Scopus, Web of Science, BIOSIS Previews, ESCI,
CAS, AGRIS, UGC-CARE, CABI, Google Scholar, etc. Full list at

CAS, AGRIS, UGC-CARE,
http://www.plantsciencetoday.online 
fruit available all over the universe. The Zizyphus mauritiana Lam is the commonly available Ber variety in India from ancient period. Prunas and Vedas illustrate the existence of Ber fruit before several centuries. It belongs to the genus Ziziphus of the family Rhamnaceae. This fruit has about 50 species and more than 600 cultivars available mostly in the tropical region of northern hemisphere. India is the origin of $Z$. mauritiana Lam and Z. jujuba Mill originated in China (1).

Well known varieties available in southern parts of India are Gola, Umran, Kaithali, Benarasi and Seb. Whereas in China, the common cultivars are Jinsixiaozao, Yazao, Jianzao, Junzao and Sambianhong. A comparison is made on the nutritional composition of these familiar varieties available in India and China. It is concluded that both the varieties are rich in nutritive content. However, Chinese variety is very rich in vitamin C when compared with Indian variety (2).

Though ber fruit contains $81 \%$ of moisture, it is rich in essential amino acids such as asparginine, arginine, glycine, glutamic acid and serine (3). It is found that the ber fruit contained more vitamin $\mathrm{C}$ and Phosphorus than apple and oranges(4).

Not only the fruits even the leaves, roots and seeds are also having various medicinal properties. The alcohol extracted from the leaves is used to stimulate the cell-mediated immune system (5). It is found that the extracts lower the cholesterol and triglycerides level in serum and liver of rats (6). Also it serves as the anti-microbial agent in preventing the growth of microorganisms such as E. coli, Staphylococcus niger and $S$. pyogenes. The anti-diarrheal activity is found in the extracts of root (7). Anti-inflammatory activity retained in the jujube fruit water extract (8). The seven identified and tested compounds from Zizhypus mauritiana seed extracts, 3,4dihydroxybenzoic acid, methyldopa, p-coumaric acid, dihydro-pcoumaric acid, rutin, isoquercetin, and kaempferol 3-O-rutinoside normally increased cell viability, reduced LDH release, and attenuated intracellular oxidative stress in PC-12 cells (9).Utilization of various biological activities of polysaccharides from Ziziphus jujuba including anti-oxidant activities, anti-tumor and hepatoprotective activities (10-13).

Though ber fruit has more nutrition and medicinal properties, it is highly perishable. Jujube fruit (Ziziphus jujuba) has thin peel crisp texture, delicious flesh and high nutritive value. These properties attract more consumers (14). Its shelf life is 2 to 4 days when it is kept at ambient temperature $\left(30\right.$ to $36^{\circ} \mathrm{C}$ ). It is considered as a functional food, due to the epidemiological evidence that a high consumption of jujube, and of all its industrial products, is correlated with a reduced risk of some types of cancers. Fruits get accumulated in the local market during the yielding period (15). Harvested jujube fruit has more physiological disorders, such as development of alcoholic fermentation, water loss, and tissue softening. These disorders make the fruit highly perishable and deteriorated easily (16). Since the fruit is of high perishable it is difficult to store and sell it in the market for a longer time. Due to the surplus of fruits in the local markets during peak season, a substantial quantity goes to waste, resulting in heavy post harvest losses (17). The foremost factors in determining the rate of post harvest deterioration of jujube fruit were physiological changes, softening and the loss of firmness these may lead to a poor quality, consumer rejection and economic loss (18).

There are very less analysis done on the post harvest research on ber fruit for last two to three decades and the information is scattered in diverse local and regional sources, especially in India (19).

Typical variety of Ber has several constraints in preserving the quality of product made out of it. To overcome the difficulties, a cross breed variety of Ber "Apple Ber" was originated in Thailand recently and it is spreading across the globe rapidly.

As the name indicates, the new cultivar resembles the shape of an Apple (Fig. 1). Not only the shape, its juiciness and crispy nature also resemble Apple. This cultivar has many advantages over the traditional ber variety.

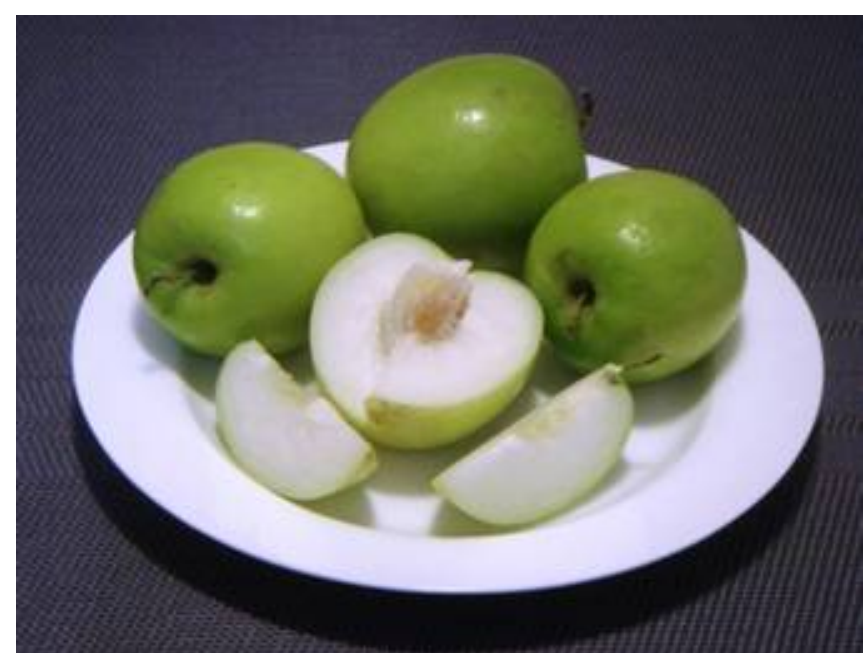

Fig. 1. Apple ber

The plant starts yielding fruits from the $6^{\text {th }}$ month of plantation. The plant withstands high temperature and drought condition. The plant yields fruits twice and particularly during the December and January. The size of the fruit is large when compared with the traditional variety and it less labour is sufficient for harvesting. This plant variety is best suitable for natural pollination. This variety stays away from various diseases which are common to the traditional ber. 


\section{Materials and Methods}

\section{Selection of the Fruits:}

A new cultivar Apple ber was collected from the local farmer. Very few cultivars were found in the southern part of India. It was found in the market during October to March. Samples were chosen for the analysis of physical and chemical properties. The samples were completely washed to remove foreign bodies and dried before the analysis was carried out. The dried fruits were ground to a fine powder. The powder was stored in an air tight container and kept at $5^{\circ} \mathrm{C}$. Moisture content of the fruit and its powder was measured at $60^{\circ} \mathrm{C}(20)$.

\section{Physical Parameter of Apple Ber:}

\section{Size and weight of the fruit}

Ten samples were chosen and the dimensions such as length and diameter were measured with the aid of digital Vernier calliper and screw gauge. The same sample was weighed using an electronic weighing scale and the mean value is registered for the analysis. Weight is measured in different ways based on the requirements for the calculations. Whole fruit weight, weight of flesh and weight of stone was measured to calculate Pulp-Stone Ratio.

\section{Pulp - Stone Ratio $\left(R_{p s}\right)$}

With the aid of the measured dimension, the pulpstone ratio was calculated using the following formula.

$$
\text { Pulp Stone ratio }\left(\mathrm{R}_{\mathrm{ps}}\right)=\frac{\begin{array}{l}
\text { Weight of the Fruit }\left(\mathrm{W}_{\mathrm{f}}\right)- \\
\text { Weight of the Stone }\left(\mathrm{W}_{\mathrm{s}}\right)
\end{array}}{\text { Weight of Stone }\left(\mathrm{W}_{\mathrm{s}}\right)}
$$

Pulp-Stone ratio forms the basis for any processing industry to finalize the quantity of fruit required to get targeted volume of fruit juice or weight of flesh for processing.

\section{Specific gravity of fruits}

Another important parameter to be calculated is Specific Gravity of the fruit. The weight of the fruit is measured in two states. First being the usual method of weighing and second by keeping the fruit submerged under water. Fruit is pushed into water with the aid of a wire loop which assures proper replacement of water from the container. Specific gravity is measured using the following formula.

$$
\text { Specific gravity }=\frac{\text { Weight of fruit in air }\left(\mathrm{W}_{\mathrm{fa}}\right)}{\begin{array}{c}
\text { Weight of fruit in air }\left(\mathrm{W}_{\mathrm{fa}}\right)-\text { Weight of } \\
\text { fruit in water }\left(\mathrm{W}_{\mathrm{fw}}\right)
\end{array}}
$$

\section{Chemical Parameters of Apple Ber:}

Chemical analysis plays a vital role in analyzing the nutritional benefits of the fruit. The common method used for the chemical analysis is derived from the manual of analysis of fruits and vegetable products (21). The properties such as Percentage of
Total Soluble Sugar, Acidity, pH, Total sugar, Juice content and Vitamin C were determined under two different conditions. The fruit was analyzed as fresh and in blanched condition.

\section{$p H$}

$\mathrm{pH}$ decides whether the fruit is acidic, basic or alkaline. The $\mathrm{pH}$ of the fruit was determined by using a digital $\mathrm{pH}$ meter. It indicates the $\mathrm{pH}$ value with the aid of standard colour code which is compared with the actual colour displayed.

\section{Total soluble solids (TSS)}

Juice is extracted from the fruit pulp which was filtered using muslin cloth and a drop is used to calculate the total soluble solids (TSS) using a hand held refractometer. TSS was expressed as ${ }^{\circ}$ Brix (22).

\section{Acidity}

Titrable acidity was determined by titrating known quantity of apple ber juice sample $(10 \mathrm{~mL})$ against standardized $0.2 \mathrm{~N} \mathrm{NaOH}$ using a few drops of 1 per cent phenolphthalein solution as indicator to achieve pink colour end point which should persist for 15 seconds.

Weight of the Fruit $\left(\mathrm{W}_{\mathrm{f}}\right)$ - Weight of the Stone $\left(W_{s}\right)$

Acidity $(\%)=\frac{10 \text { (volume of sample taken) }}{1}$

\section{Reducing sugars}

To $25 \mathrm{~g}$ of the sample in a volumetric flask $100 \mathrm{~mL}$ of water was added and neutralized with $1 \mathrm{~N}$ $\mathrm{NaOH} .2 \mathrm{~mL}$ of $66 \%$ lead acetate solution was added and kept for 10 minutes. Excess lead acetate was precipitated by necessary amount of $20 \%$ potassium oxalate, made up to the volume with water, filtered and taken in burette. $10 \mathrm{~mL}$ of mixed Fehling's solution was taken in $250 \mathrm{~mL}$ conical flask. Little quantity of the sample was run into flask and heated to boil moderately for 2 minutes. 3 drops of methylene blue solution was added and completed the titration until the indicator was completely decolourized. Brick red colour of the solution indicates the end point (23).

\section{Total sugars}

For total sugars $50 \mathrm{~mL}$ of filtered sample was taken in a $200 \mathrm{~mL}$ conical flask to which $50 \mathrm{~mL}$ water and $5 \mathrm{~g}$ of citric acid was added, boiled gently for 10 minutes to complete the inversion of sucrose, transferred to $250 \mathrm{~mL}$ volumetric flask and neutralized with $1 \mathrm{~N} \mathrm{NaOH}$. The volume was made up to the mark and determined the total sugars as invert sugars (24).

\section{Ascorbic acid (mg/100 mL or mg/100 g sample)}

Ascorbic acid was estimated by visual titration method. $10 \mathrm{~mL}$ of the sample was made up to 100 $\mathrm{mL}$ with $3 \%$ metaphosphoric acid and filtered. To estimate the interference of sulphur dioxide in the 
sample, $10 \mathrm{~mL}$ of the filtrate was taken and added with $1 \mathrm{~mL}$ of $40 \%$ formaldehyde and $0.1 \mathrm{~mL}$ of $\mathrm{HCl}$ and kept for 10 minutes. The sample was titrated with the standard 2.6-dichlorophenol-indophenol dye to a pink end-point that should persist for at least 15 seconds.

\section{TSS-acid ratio}

It was calculated by dividing TSS value with titratable acidity of the juice.

\section{Storage studies:}

The fruits harvested needs to be stored until it reaches the processing station. Hence, it is essential to study the parameter which impacts the storage life such as decay, skin browning, shrinking change in flavor, taste, etc., at ambient and refrigerator atmosphere. Apart from storage life it is essential to analyze the Physiological loss in weight (PLW) also. It can be calculated using the following formula.

\section{Physiological loss in weight (\%):}

It was determined by periodic weighing of ber fruits and expressed as percentage of its initial weight by following formula:

$$
\begin{aligned}
& \% P L W=W_{i}-W_{f} / W_{i} X 100 \\
& \text { Where, PLW = Physiological loss in weight } \\
& \mathrm{W}_{\mathrm{i}}=\text { Initial weight of ber fruits kept for storage } \\
& \mathrm{W}_{\mathrm{f}}=\text { Final weight of ber fruits on selected days after } \\
& \text { harvesting. }
\end{aligned}
$$

\section{Sensory evaluation:}

Apart from physical and chemical analysis, sensory evaluation techniques were used to estimate the physico-morphological qualities like texture, taste, odor and skin color. The opinion collected from the panel of experts using 5 point hedonic scale determines the quality of fruits.

\section{Proximate analysis:}

Proximate analysis uses neither sophisticated equipments nor chemicals to estimate the main components of a food. It is used to analyse moisture, fibre, ash, proteins and carbohydrates from the fruit and its seed. Difference in the weight is used to determine ash and moisture. The sum of percentages of ash, moisture, extract, crude fibre and crude protein subtracted from 100 gives the presence of carbohydrate. Fibre content was estimated from the loss in weight of the crucible and its content on ignition.

\section{Apple ber powder enriched products}

The Apple Ber powder is used to prepare value added products which can be commercial produced and served to the society to improve their health condition. Cake, cookies and chocolates are loved by all age people. Enriching Apple ber powder to these products increases the health benefits. Since the Apple ber has better shelf life, the manufacturers' faces fewer problems in preserving the fruit.

Table 1 depicts the ingredients used to prepare the products enriched with Apple Ber powder.

Table 1. List of ingredients used

\begin{tabular}{lccc}
\hline \multicolumn{1}{c}{ Ingredients } & Cake & Cookies & Chocolate \\
\hline Wheat (gm) & 20 & 20 & - \\
\hline Ber fruit powder (gm) & 5 & 5 & 15 \\
\hline Milk Powder (g) & - & - & 35 \\
\hline Cocoa Powder (g) & - & - & 30 \\
\hline Jaggery (gm) & 25 & 10 & 20 \\
\hline Butter (gm) & 25 & 15 & - \\
\hline Egg & 1 & - & - \\
\hline Baking powder & a Pinch & a Pinch & - \\
\hline Vanilla essence & Few drops & Few drops & - \\
\hline
\end{tabular}

In the commercial product preparation, Maida and sugar is used to prepare cake and cookies. These materials are proved to be very hazards to human health. Hence, the products enriched with Apple ber powder is produced using wheat and Jaggery. These value added products serves as a nutritious food without comprising on the taste and quality of the commercially available food in the market. The preparation methods of apple ber enriched products are given below.

\section{Procedure for Cake preparation}

1. Sieve flour with baking powder twice

2. Beat the egg white light and frothy

3. Beat the egg yolk and butter together

4. Add jaggery little by little and cream well

5. Add sieved flour little by little and mix well

6. Add the egg white and fold gently

7. Pour it on the greased mold

8. Bake at $200^{\circ} \mathrm{C}$ for 20 minutes

\section{Procedure for Cookies preparation}

1. Creaming the butter and sieve the dry ingredients and mix well with jaggery

2. Mixing (creamed butter + dry ingredients)

3. To make the dough

4. Sheeting and cutting

5. Bake at $150^{\circ} \mathrm{C}$ for 15 minutes

\section{Procedure for Chocolate preparation}

1. Sieve all the dry ingredients

2. Prepare the jaggery syrup

3. Add the dry ingredients into the jaggery syrup

4. Stir it well

5. Pour it into greased plate and cool it

6. Cut into desired shape

7. packed it in the aluminium foil and store it 


\section{Microbial analysis of ber fruit powder incorporated products:}

Microbial count was carried out in Ber fruit (Zizyphus mauritiana) powder enriched products at 15 days interval. The polythene covered products were stored at room temperature and refrigeration. For this study, the proportion of products were homogenized, serially diluted in appropriate dilutes, plated in a suitable agar medium, incubated at an appropriate temperature for a given time, after which all visible colonies were counted by the use of electronic counter. The number of microbes was tested by SPC (standard plate count) method. The agar agar was used for fungal counts. The incubation time for nutrient agar plate was 24 hours.

\section{Statistical Analysis:}

The data were analyzed using SPSS. All results are expressed as the mean \pm standard deviation (SD) of three replicates. t-test was used to evaluate difference between samples. All of the statistical differences were carried out at a significance level of $a<0.05$.

\section{Results and Discussion}

\section{Physical characteristics of apple ber}

Table 2 depicts the comparison of physical parameters of blanched and controlled fruits. Each value in the table was obtained by calculating the average of ten experiments and the data are presented as Mean \pm Standard Deviation. The mean fruit and stone weight, height, diameter and pulp stone ratio were $65.5 \pm 5.4 \mathrm{~g}, 4.98 \pm 0.22 \mathrm{~cm}$, $4.42 \pm 0.16 \mathrm{~cm}, 7.1 \pm 2.7 \mathrm{~g}, 1.2 \pm 0.1 \mathrm{~cm}, 2.26 \pm 0.11 \mathrm{~cm}$ and $7.3 \pm 2.44$ for normal control fruit.

Table 2. Physical Characteristics of Apple Ber

\begin{tabular}{lccc}
\hline Physical Properties & Control & Blanched & $\begin{array}{c}\text { Significant } \\
\text { Difference } \\
P<0.05\end{array}$ \\
\hline Fruit Weight $(\mathrm{gm})$ & $65.5 \pm 5.4$ & $62.3 \pm 6.3$ & 0.421 \\
\hline Fruit Height $(\mathrm{cm})$ & $4.98 \pm 0.22$ & $3.98 \pm 0.34$ & 0.008 \\
\hline Fruit Diameter $(\mathrm{cm})$ & $4.42 \pm 0.16$ & $4.26 \pm 0.23$ & 0.222 \\
\hline Stone Weight $(\mathrm{gm})$ & $7.1 \pm 2.7$ & $6.8 \pm 2.1$ & 0.690 \\
\hline Stone Height $(\mathrm{cm})$ & $1.2 \pm 0.1$ & $1.2 \pm 0.1$ & 1.00 \\
\hline Stone Diameter $(\mathrm{cm})$ & $2.26 \pm 0.11$ & $2.24 \pm 0.1$ & 0.841 \\
\hline Pulp Stone Ratio & $7.3 \pm 2.44$ & $7.0 \pm 2.7$ & 0.670 \\
\hline
\end{tabular}

*Statistically significant differences between the control and blanched sample ofphysical characteristics of Apple ber fruit.

In blanched environment the mean fruit and stones weight, height, diameter and pulp stone ratio were $62.3 \pm 6.3 \mathrm{~g}, 3.98 \pm 0.34 \mathrm{~mm}, 4.26 \pm 0.23 \mathrm{~mm}$, $6.8 \pm 2.1 \mathrm{~g}, 1.2 \pm 0.1 \mathrm{~mm}, 2.2 \pm 0.1 \mathrm{~mm}$ and $7 \pm 2.7$. There was decrease in all the physical parameters of fruit and stone after the process of blanching, whereas the stone height remained the same even after blanching. Significant differences between the controlled and blanched are shown in Table 2.

\section{Chemical characteristics of apple ber}

The chemical properties of blanched fruit was compared with control and assessed as in Table 3. Each value in the table was obtained by calculating the average of three experiments and the data are presented as Mean \pm Standard Deviation. The TSS, Acidity, $\mathrm{pH}, \mathrm{TSS} /$ Acid ratio, Juice content, Reducing sugar, Vitamin C and specific gravity values were determined. Significant reduction has been found in chemical parameters such as TSS, Acidity, pH, TSS/Acid ration, reducing sugar and specific gravity after blanching process. Whereas there was increase in the TSS/Acid ration, Juice content of the fruit after blanching. Significant differences between the controlled and blanched are shown in Table 3. From the statistical analysis, it is found that the control ber fruit is suitable for the experimental study.

Table 3. Chemical Characteristics of Apple Ber

\begin{tabular}{lccc}
\hline \multicolumn{1}{c}{ Chemical Properties } & Control & Blanched & $\begin{array}{c}\text { Significant } \\
\text { Difference } \\
P<0.05\end{array}$ \\
\hline TSS ('Brix) & $8.4 \pm 0.32$ & $6.4 \pm 0.16$ & 0.008 \\
\hline Acidity (\%) & $\begin{array}{c}0.21 \pm 0.0 \\
5\end{array}$ & $0.23 \pm 0.2$ & 0.690 \\
\hline pH & $4.9 \pm 0.1$ & $4.2 \pm 0.2$ & 0.008 \\
\hline TSS/Acid Ratio & $30.1 \pm 1.7$ & $34.5 \pm 0.42$ & 0.008 \\
\hline Juice Content (\%) & $52.4 \pm 1.4$ & $33.8 \pm 4.6$ & 0.320 \\
\hline Reducing Sugar (\%) & $1.82 \pm .05$ & $1.52 \pm 1.6$ & 0.008 \\
\hline Non-Reducing Sugar (\%) & $5.2 \pm 0.3$ & $4.4 \pm 0.43$ & 0.032 \\
\hline Total Sugar (\%) & $7.2 \pm 0.3$ & $6.12 \pm 0.42$ & 0.008 \\
\hline Vitamin C (m) & $64.6 \pm 2.8$ & $52.8 \pm 4.1$ & 0.008 \\
\hline Specific Gravity & $0.34 \pm 0.9$ & $0.12 \pm 0.4$ & 0.008 \\
\hline
\end{tabular}

*Statistically significant differences between control and blanched sample of chemical characteristics of Apple ber fruit.

\section{Proximate Analysis of Ber Fruit Seed}

The result of the proximate composition of ber fruit seed was shown (Table 4) to be the moisture (11.62\%), ash (5.10\%). Fibre (10.30\%), Carbohydrate $(37.51 \%)$, Protein $(24.65 \%)$ and fat (22.44\%). This study reveals that apple ber fruit seed have low moisture, high fat and protein content.

Table 4. Proximate analysis of Apple ber seed

\begin{tabular}{clc}
\hline S. No & \multicolumn{1}{c}{ Analysis } & Results \\
\hline 1 & Moisture content (\%) & 11.62 \\
\hline 2 & Total Ash (\%) & 5.10 \\
\hline 3 & Fiber (\%) & 10.30 \\
\hline 4 & Carbohydrates (\%) & 37.51 \\
\hline 5 & Protein (\%) & 24.65 \\
\hline 6 & Fat (\%) & 22.44 \\
\hline
\end{tabular}

\section{Physiological Loss in Weight (PLW) of Fruit}

Physiological weight loss evaluation before and after refrigeration and room conditions are showed in Table 5 . Whereas there was no weight 
loss was measured till the $2^{\text {nd }}$ day of storage at normal RT. But on $8^{\text {th }}$ day, the maximum weight loss recorded was $42 \%$ in room temperature and only $6 \%$ of weight loss was recorded in refrigerator temperature. Development of dark brown spot on the pericarp of fruit skin within 5-8 days stored at ambient condition was seen.

Table 5. Physiological Loss in Weight (PLW) of Fruit

\begin{tabular}{lcccc}
\hline \multirow{2}{*}{ Storage Conditions } & \multicolumn{4}{c}{ PLW (\%) } \\
\cline { 2 - 5 } & 0 day & $3^{\text {rd }}$ day & $6^{\text {th }}$ day & $8^{\text {th }}$ day \\
\hline Room Condition & 0 & 35 & 38 & 42 \\
\hline Refrigerator Condition & 0 & 4 & 5 & 6 \\
\hline
\end{tabular}

\section{Subjective Maturity Parameter and Quality Attributes (Ambient condition)}

Quality and freshness of the fruit can be partially judged using the color of the fruit. Skin color, Pulp Texture, Taste and attractiveness of the fruit is rated using sensory evaluation as depicted in Table 6.

Table 6. Subjective Maturity Parameter and Quality Attributes (Ambient condition)

\begin{tabular}{|c|c|c|c|c|}
\hline & \multicolumn{2}{|c|}{ Maturity Parameter } & \multicolumn{2}{|c|}{ Quality Attributes } \\
\hline $\begin{array}{c}\text { Storage } \\
\text { Days }\end{array}$ & Skin Colour & $\begin{array}{l}\text { Pulp } \\
\text { Texture }\end{array}$ & Taste & $\begin{array}{l}\text { Attractiveness } \\
\text { of Fruits }\end{array}$ \\
\hline $3^{\text {rd }}$ day & Dark Green & Crispy & Very Good & Attractive \\
\hline $6^{\text {th }}$ day & $\begin{array}{l}\text { Yellowish } \\
\text { Green }\end{array}$ & Crispy & Good & $\begin{array}{l}\text { Very much } \\
\text { Attractive }\end{array}$ \\
\hline $8^{\text {th }}$ day & $\begin{array}{c}\text { yellowish } \\
\text { Green with } \\
\text { Shriveling } \\
\text { and brown } \\
\text { spots }\end{array}$ & Crispy & Fair & Less Attractive \\
\hline
\end{tabular}

The fruit is exposed in two different conditions. Fruit is kept under ambient condition and the changes in the parameters based on the number of days were recorded as shown in the table. Also the fruit is kept in the refrigerator and the parameters were recorded. The analysis shows that there is change in the color with respect in increase in storage period however no significant changes occurred in the pulp texture. Slow Deterioration is witnessed in the taste and attractiveness of the fruit over a period of time.

\section{Refrigerated condition:}

Fig. 2 depicts the level decomposition of the fruit under refrigerated under ambient condition. Till the $8^{\text {th }}$ day, the fruit didn't decompose in the refrigerated condition. Almost the freshness of the fruit is maintained hence the fruit can be used to manufacture many value added products which can be stored for a longer time under preserved condition.

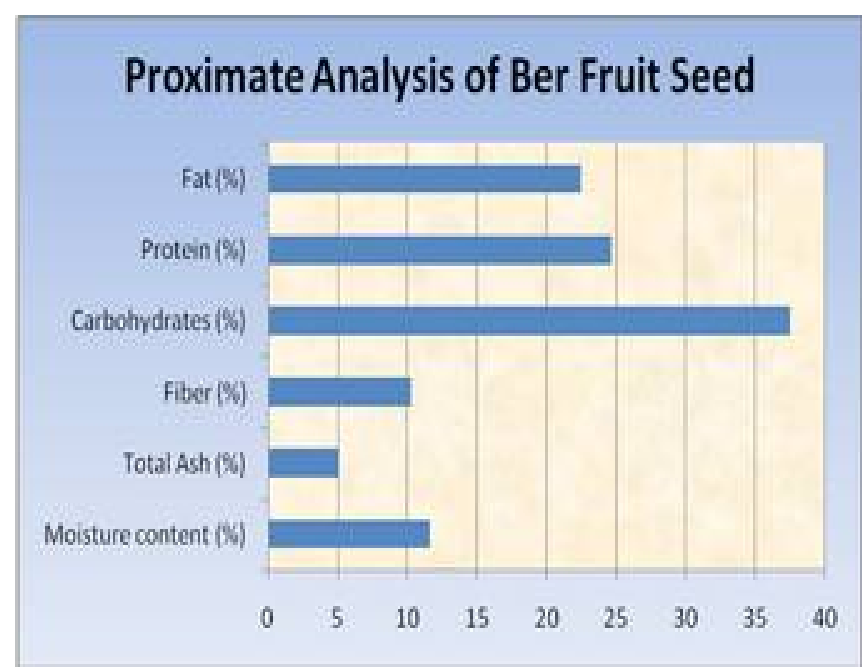

Fig. 2. Proximate Analysis of Ber Fruit Seed

Progress of decomposition in the ambient condition is depicted in Fig. 3. Each and every day the fruit is analyzed for the change of color and texture. Until day 8 , the quality of fruit is acceptable and from day 10 the process of decomposition is at higher rate.

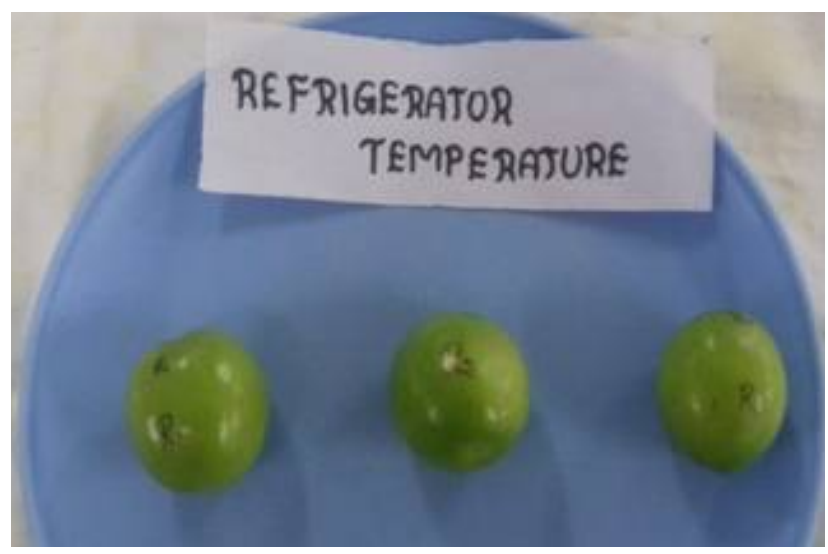

Fig. 3. Apple Ber under refrigerated condition

Table 7. Sensory Evaluation of Apple Ber fruit during storage

\begin{tabular}{lcccccc}
\hline & \multicolumn{2}{c}{ 3rd day } & \multicolumn{2}{c}{ 6th day } & \multicolumn{2}{c}{ 8th day } \\
\hline Characters & AT & RT & AT & RT & AT & RT \\
\hline Colour & $4.3 \pm 0.3$ & $4.8 \pm 0.1$ & $3.7 \pm 0.2$ & $4.9 \pm 0.1$ & $3.4 \pm 0.29$ & $4.72 \pm 0.09$ \\
\hline Flavour & $4.5 \pm 0.31$ & $4.9 \pm 0.1$ & $3.9 \pm 0.24$ & $4.74 \pm 0.10$ & $3.5 \pm 0.15$ & $4.74 \pm 0.09$ \\
\hline Texture & $4.3 \pm 0.3$ & $4.7 \pm 0.2$ & $3.7 \pm 0.12$ & $4.78 \pm 0.11$ & $3.76 \pm 0.40$ & $4.56 \pm 0.16$ \\
\hline Appearance & $4.3 \pm 0.3$ & $4.8 \pm 0.09$ & $3.94 \pm 0.26$ & $4.7 \pm 0.12$ & $3.7 \pm 0.33$ & $4.66 \pm 0.99$ \\
\hline Overall acceptability & $4.5 \pm 0.3$ & $4.9 \pm 0.1$ & $3.9 \pm 0.29$ & $4.8 \pm 0.12$ & $3.7 \pm 0.33$ & $4.7 \pm 0.12$ \\
\hline
\end{tabular}




\section{Sensory evaluation:}

The colour, flavor, texture and appearance of the apple ber fruit during storage is estimated using sensory evaluation. 5 point hedonic scale is depicted in Table 7.

Overall acceptability of the fruit in the ambient condition diminishes day by day from $4.5 \pm 0.3$ in $3^{\text {rd }}$ day to $3.7 \pm 0.33$ on $8^{\text {th }}$ day. Similarly in the refrigerated condition the overall acceptability reduces at a lower rate when compared with the ambient condition. It reduces from $4.9 \pm 0.1$ to $4.7 \pm 0.12$ which is very close to the fresh condition. Thus, the fruit undergoes less deterioration under refrigerated condition.

\section{Proximate Analysis of Apple ber:}

Table 8 shows that the proximate analysis of the apple ber on wet basis. It compares the controlled sample with the blanched one.

Table 8. Proximate Analysis of Apple ber in Wet Basis

\begin{tabular}{lrc}
\hline & \multicolumn{2}{c}{ Wet Basis } \\
\hline Energy (Kcal/100g) & Control & Blanched \\
\hline Moisture (\%) & 36.4 & 34.8 \\
\hline Protein (g) & 90.2 & 90.9 \\
\hline Fat (g) & 1.7 & 1.0 \\
\hline Fiber (g) & $<0.1$ & $<0.1$ \\
\hline Ash (\%) & 6.4 & 4.4 \\
\hline Total Sugar (g) & 0.7 & 0.4 \\
\hline Calcium (mg) & 1.60 & 1.25 \\
\hline Ascorbic acid (mg) & 32 & 28.4 \\
\hline
\end{tabular}

The energy per 100 grams is 1.6 gm higher in control than the blanched. Moisture content is approximately equal in both the cases. 0.7 grams higher protein is available in control than the blanched. Fat is almost the same however there is a significant difference in the presence of fiber. Fiber in the control is 5 gms higher than the blanched is witnessed in the analysis. Very less percentage of ash is present in the blanched when compared with the control. Around $0.3 \%$ difference is found in the Ash content. Higher values of Calcium and Ascorbic acid were present in the controlled condition.

Table 9 depicts the proximate analysis of the Apple ber on Dry basis. Apple ber is dried using micro wave oven in 4 different temperatures.

Table 9. Proximate Analysis of Apple ber in Dry Basis

\begin{tabular}{lcc}
\hline & \multicolumn{2}{c}{ Dry Basis } \\
\hline & Control & Blanched \\
\hline Energy (Kcal/100g) & 86.23 & 82.37 \\
\hline Moisture (\%) & 10.4 & 11.7 \\
\hline Protein (g) & 0.36 & 0.32 \\
\hline Fat (g) & 1.20 & 1.08 \\
\hline Fiber (g) & 8.40 & 6.24 \\
\hline Ash (\%) & 4.65 & 4.32 \\
\hline Total Sugars (g) & 48.65 & 36.43 \\
\hline Calcium (mg) & 12.4 & 10.18 \\
\hline Ascorbic acid (mg) & 72 & 68 \\
\hline
\end{tabular}

Analysis of Apple Ber in Dry Basis four chosen temperatures were $50^{\circ} \mathrm{C}, 55^{\circ} \mathrm{C}, 60^{\circ} \mathrm{C}$ and $65^{\circ} \mathrm{C}$ which little higher than the room temperature. Among these four temperatures $60^{\circ} \mathrm{C}$ is chosen for the study. High yield of fruit powder is obtained from apple ber at $60^{\circ} \mathrm{C}$. Since there is no significant losses occurred in the nutritional values. The Table 9 shows the controlled condition tops in all the aspects when compared to the blanched. Though the difference is very meager in many parameters, significant difference is witnessed in total sugar.

\section{Nutritional Comparison between Apple ber with Traditional ber}

Table 10 depicts the comparison of nutritional analysis of the Apple ber with traditional variety. It shows that the Apple ber variety shows a significant difference in various aspects. Energy level is $36.4 \mathrm{kcal} / 100 \mathrm{gms}$ which is double the value of traditional variety. This will be a major factor to be considered in developing a nutritive new product with more calorific value. Similarly Protein, fibre, ash content, calcium and ascorbic acid were found higher in apple ber compared with traditional variety. However, fat and total sugar found to be lesser that the traditional ber fruit. Apple ber fruits are rich in vitamins and minerals; hence consumption of one apple ber in a day would meet the nutritional requirements of an adult to stay healthy.

Table 10. Nutritional Comparison between Apple ber with Traditional ber

\begin{tabular}{lcc}
\hline & \multicolumn{2}{c}{ Wet Basis } \\
\hline & Apple Ber & $\begin{array}{c}\text { Traditional Ber } \\
\text { Variety }\end{array}$ \\
\hline Energy (Kcal/100g) & 36.4 & 17 \\
\hline Moisture (\%) & 90.2 & $81-83$ \\
\hline Protein (g) & 1.7 & 0.8 \\
\hline Fat (g) & $<0.1$ & 0.07 \\
\hline Fiber (g) & 6.4 & 0.60 \\
\hline Ash (\%) & 0.7 & $0.3-0.59$ \\
\hline Total Sugar (g) & 1.60 & 5.4 \\
\hline Calcium (mg) & 32 & 25.6 \\
\hline Ascorbic acid (mg) & 67 & 65 \\
\hline Reducing Sugar (\%) & 1.82 & 1.4 \\
\hline Non-Reducing Sugar (\%) & 5.2 & 3.2 \\
\hline
\end{tabular}

\section{Sensory Evaluation of Apple ber powder Enriched Products}

Table 11 depicts the sensory evaluation of the products enriched with Apple ber powder. Cake, cookies and chocolates produced were analyzed for its color, flavor, texture, taste and overall acceptance.

In all the aspects, cookies top the other products. It is followed by cake and chocolate stands the last. Cookies were found to have natural aroma and taste which was liked by many people. 
Table 11. Sensory Evaluation of the Enriched Products

\begin{tabular}{lcrc}
\hline \multicolumn{1}{c}{ Characters } & Cake & Cookies & Chocolate \\
\hline Color & $4.3 \pm 0.2$ & $4.9 \pm 0.1$ & $4.2 \pm 0.2$ \\
\hline Flavor & $3.5 \pm 0.15$ & $4.74 \pm 0.10$ & $4.3 \pm 0.2$ \\
\hline Texture & $3.8 \pm 0.12$ & $4.78 \pm 0.11$ & $4.2 \pm 0.2$ \\
\hline Taste & $3.8 \pm 0.31$ & $4.7 \pm 0.12$ & $4.4 \pm 0.24$ \\
\hline $\begin{array}{l}\text { Over all } \\
\text { acceptability }\end{array}$ & $4.46 \pm 0.25$ & $4.7 \pm 0.12$ & $4.37 \pm 0.23$ \\
\hline
\end{tabular}

\section{Microbial Analysis of Apple ber Fruit Powder}

In microbial analysis, the above Table 12 depicts the result of the microbial load of control and blanched ber fruit powder was kept in room temperature and refrigeration temperature. During the analysis, it was found that the powders had too few to count microorganisms at refrigeration temperature where the samples had too numerous to count microorganisms at room temperature. Since the microbial count is very less, it is suitable for edible purpose.

Table 12. Microbial Analysis of Ber Fruit Powder

\begin{tabular}{|c|c|c|c|c|c|c|c|}
\hline \multirow[t]{2}{*}{$\begin{array}{l}\text { Sample } \\
\text { Ber Fruit } \\
\text { Powder }\end{array}$} & \multirow[t]{2}{*}{ Microbes } & \multicolumn{3}{|c|}{$\begin{array}{c}\text { Microbial load at } \\
\text { room } \\
\text { temperature }\end{array}$} & \multicolumn{3}{|c|}{$\begin{array}{l}\text { Microbial load at } \\
\text { Refrigeration } \\
\text { temperature }\end{array}$} \\
\hline & & Initial & $\begin{array}{l}\text { 15th } \\
\text { day }\end{array}$ & $\begin{array}{l}\text { 30th } \\
\text { day }\end{array}$ & nitial & $\begin{array}{l}\text { 15th } \\
\text { day }\end{array}$ & 30th day \\
\hline Control & Bacteria & - & TFTC & TFTC & - & TFTC & TFTC \\
\hline Blanched & Bacteria & - & TFTC & TNTC & & TFTC & TFTC \\
\hline
\end{tabular}

\section{Conclusion}

The new variety is analyzed from the physicochemical perspectives and found that the controlled condition sample is superior in all the aspects. Many products can be produced using this new cultivar since it has a very good storage and shelf life which is essential to preserve the food for a longer time. Out of the three products produced using the Apple ber powder, Cookies is liked by many people because of its natural flavor and taste. These kinds of products are essential to human kind to stay healthy and live long.

\section{Acknowledgements}

The authors would like to acknowledge the continuous support rendered by V.V. Vanniaperumal College for Women, Virudhunagar in completing this work successfully.

\section{Conflict of Interest}

We hereby declare that we have no conflict of interest.

\section{Authors' contribution}

We declare that we have contributed equally to the work presented in the research article.

\section{References}

1. Baily LH. The Standard Cyclopedia of Horticulture. $2^{\text {nd }}$ ed. MacMillan and Co. New York: 1947;3457-58. https://doi.org/10.5962/bhl.title.25505

2. Pareek S. Nutritional composition of jujube fruit. Emirates Journal of Food and Agriculture 2013, 25(6):463-70. https://doi.org/10.9755/ejfa.v25i6.15552

3. Azam-Ali S, Bonkoungou E, Bowe C, DeKok C, Godara A, Williams JT (eds) Ber and other jujubes. In: Fruits for the future 2. International Centre for Underutilized Crops, University of Southampton, Southampton, SO17 1BJ, UK, 2006; 18-29.

4. Obeed RS, Harhash MM, Abdel-Mawgood AL. Fruit properties and genetic diversity of five ber (Ziziphus mauritiana Lam.) cultivars. Pakistan Journal of Biological $\quad$ Sciences $2008 ; 11(6)$ : $\quad 888-93$ https://doi.org/10.3923/pjbs.2008.888.893

5. Wadekar RR, Patil KS. Effect of Ziziphus mauritiana leaf extracts on phagocytosis by human neutrophils. Journal of Pharmacy Research 2008;1(1): 79-83.

6. Dahiru D, Obidoa O. Pretreatment of albino rats with aqueous leaf extract of Ziziphus mauritiana protects against alcohol-induced liver damage. Tropical Journal of Pharmaceutical Research 2007;6(2): 705-10. http://dx.doi.org/10.4314/tjpr.v6i2.14649

7. Dahiru D, Sini JM, John-Africa L. Anti diarrhoeal activity of Ziziphus mauritiana root extract in rodents. African journal of biotechnology 2006; 5(10):941-45.

8. Chen J, Du CY, Lam KY, Zhang W L, Lam CT, Yan AL, Tsim KW. The standardized extract of Ziziphus jujuba fruit (Ziziphus mauritiana) regulates pro-inflammatory cytokine expression in cultured murine macrophages: suppression of lipopolysaccharide-stimulated NF- $\mathrm{kB}$ activity. Phytotherapy research 2014; 28(10): 1527-32. http://doi.org/10.1002/ptr.5160.

9. Choi J, An X, Lee BH, Lee J S, Heo HJ, Kim T, Kim DO. Protective effects of bioactive phenolics from jujube (Ziziphus mauritiana) seeds against $\mathrm{H} 2 \mathrm{O}$ 2-induced oxidative stress in neuronal PC-12 cells. Food science and biotechnology 2015; 24(6): 2219-27. http://doi.org/10.3889/oamjms.2018.168.

10. Li J, Liu Y, Fan L, Ai L, Shan L. Antioxidant activities of polysaccharides from the fruiting bodies of Ziziphus mauritiana cv. Jinsi xiaozao. Carbohydrate $\begin{array}{llll}\text { Polymers } & \text { 2011; } & \text { 84(1): } & \text { 390-94 }\end{array}$ http://doi.org/10.1016/j.carbpol.2010.11.051

11. Wang D, Zhao Y, Jiao Y, Yu L, Yang S, Yang $\mathrm{X}$. Antioxidative and hepatoprotective effects of the polysaccharides from Zizyphus jujube $\mathrm{cv}$. Shaanbeitanzao. Carbohydrate Polymers 2012; 88(4): 1453-59. http://doi.org/10.1016/j.carbpol.2012.02.046

12. Yamada H, Nagai T, Cyong JC, Otsuka Y, Tomoda M, Shimizu N, Shimada K. Relationship between chemical structure and anti-complementary activity of plant polysaccharides. Carbohydrate research 1985; 144(1): 101-11. https://doi.org/10.1016/0008-6215(85)85011-4

13. Chi A, Kang C, Zhang Y, Tang L, Guo H, Li H, Zhang K. Immuno modulating and antioxidant effects of polysaccharide conjugates from the fruits of Ziziphus Jujube on Chronic Fatigue Syndrome rats. Carbohydrate polymers 2015;122:189-96. http://doi.org/10.1016/j.carbpol.2014.12.082

14. Lu H, Lou $\mathrm{H}$, Zheng $\mathrm{H}, \mathrm{Hu} \mathrm{Y}$, Li Y. Non-destructive evaluation of quality changes and the optimum time for harvesting during jujube (Zizyphus jujuba Mill. cv. Chang hong) fruits development. Food and bioprocess 
technology 2012;
https://doi.org/0.1007/s11947-011-0640-5

15. Bhatia A, Mishra T. Hypoglycemic activity of Ziziphus mauritiana aqueous ethanol seed extract in alloxaninduced diabetic mice. Journal of Pharmaceutical biology 2010; 48(6): 604-10. https://doi.org/10.3109/13880200903218935

16. Zhang L, Li S, Dong Y, Zhi H, Zong W. Tea polyphenols incorporated into alginate-based edible coating for quality maintenance of Chinese winter jujube under ambient temperature. LWT-Food Science and Technology 2016;70:155-61. https://doi.org/10.1016/j.lwt.2016.02.046

17. Pareek S, Kitinoja L, Kaushik, RA, Paliwal R. Postharvest physiology and storage of ber. Stewart Postharvest Review 2009;5(5):1-10. https://doi.org/10.2212/spr.2009.5.5

18. Zhao Y, Zhu X, Hou Y, Wang X, Li X. Effects of nitric oxide fumigation treatment on retarding cell wall degradation and delaying softening of winter jujube (Ziziphus jujuba Mill. cv. Dongzao) fruit during storage. Postharvest Biology and Technology 2019; 156:110954. https://doi.org/10.1016/j.postharvbio.2019.110954
19. Gao $\mathrm{QH}, \mathrm{Wu} \mathrm{CS}$, Wang $\mathrm{M}$. The jujube (Ziziphus jujuba Mill.) fruit: a review of current knowledge of fruit composition and health benefits. Journal of agricultural and food chemistry 2013; 61(14): 3351-63. https://doi.org 10.1021/jf4007032

20. Pareek S, Yahia EM. Postharvest biology and technology of ber fruit. Horticultural reviews 2013; 201-40. http://doi.org/10.1002/9781118707418.ch05

21. Sullivan DM, Carpenter DE. (Eds.). Methods of analysis for nutrition labeling (No. 543/S949). Arlington, VA AOAC International; 1993.

22. Ranganna S. Handbook of analysis and quality control for fruit and vegetable products. Tata McGraw-Hill Education: 1986

23. Lane JH. Determination of reducing sugar by means of Fehling's solution with methylene blue as internal indicator. Journal of the Society of Chemical Industry, 1923; 17:32-37.

24. Ranganna S. Manual of analysis of fruit and vegetable products; 1977. 